\title{
Kilzinliiil fil-네№il $=$ \\ PENGEMBANGAN KOLEKSI UNTUK PROGRAM INTERNASIONALISASI JURNAL BIDANG GEOSAINS DI INDONESIA: ANALISIS SITASI
}

\author{
Himawanto*, Luki Wijayanti**
}

Pengutipan: Himawanti., dan Wijayanti, L. (2018). Pengembangan koleksi untuk program internasionalisasi jurnal bidang geosains di Indonesia: analisis sitasi. Khizanah al-Hikmah : Jurnal Ilmu Perpustakaan, Informasi, dan Kearsipan, 6(1), 55-66.

DOI: $10.24252 /$ kah.v6a1a6

\author{
*Perpustakaan Puslitbangtek Migas "LEMIGAS" \\ **Universitas Indonesia \\ himawanto@lemigas.esdm.go.id, luki_w@ui.ac.id
}

\begin{abstract}
ABSTRAK
Dengan analisis sitasi, penelitian ini menginvestigasi frekuensi pengutipan, usia sitasi, penerbit, dan indeks tertimbang jurnal pada dua terbitan berkala geosains program internasionalisasi periode 20142016. Hasil menunjukkan dari 1742 referensi yang dianalisis, koleksi jurnal lebih diperhitungkan dengan jumlah sitasi hingga $58.27 \%$. Sitasi secara berulang sebesar $40.2 \%$ dari 408 judul, mengindikasikan adanya kontribusi jurnal-jurnal lain yang lebih besar untuk kesempurnaan artikel penulis. Distribusi usia sitasi yang ditampilkan untuk manajemen penyediaan akses, penyimpanan, dan penyiangan, diketahui rasionya 17.06 dengan rentang 0-126 tahun. Kendati masih lebih pendek dari sejumlah studi yang pernah dilaporkan, sitasi jurnal berusia tinggi membuktikan mutunya terbangun secara baik. Temuan lainnya, terdapat 191 penerbit dimana Elsevier, Wiley, dan Springer lebih diminati penulis. Tren ini dapat menjadi landasan untuk mempertahankan sejumlah penerbit sebagai penyedia jurnal. Fakta menarik lain, para penulis tidak selamanya mengandalkan sumber jurnal terindeks Scopus. Bahkan menurut peringkat indeks tertimbang, jurnal-jurnal Indonesia mampu bersaing dan teruji manfaatnya. Sebagai upaya kesinambungan serta percepatan internasionalisasi jurnal-jurnal geosains lainnya di Indonesia, konsistensi perpustakaan termasuk diandalkan melalui pengembangan koleksi serial tepat guna dan berkualitas.
\end{abstract}

Kata kunci: Pengembangan koleksi; analisis sitasi; geosains; jurnal ilmiah

\section{ABSTRACT}

By citation analysis, the study investigated the citation frequencies, citation ages, publishers, and weighted index published in two internationalization program geoscience journals for the period 2014-2016 are examined to find. Results show that from 1742 references analyzed, journal collection is more taken into account with 58.27\% citation. Repeated citation reached $40.2 \%$ of 408 titles, indicates the existence contribution of other journals which larger for author article perfections. Citation age distributions which displayed for management of access, storage and weeding, is known ratio reached 17.06 with 0-126 year range. Although still shorter than studies have ever been reported, old journal citations prove their quality is well established. Another finding, there are 191 publishers where Elsevier, Wiley, and Springer are more in demand by authors. This trend can be basis for retaining a number of publishers as journal providers. Another interesting fact, the authors not always rely on Scopus indexed journal sources. Even according to weighted index rating, Indonesian journals are able to compete and have proven their benefits. As an sustain effort and accelerating the internationalization of other geoscience journals in Indonesia, the consistency of libraries include be relied through journal collection development which appropriate and qualified.

Keywords: Collection development; citation analysis; geosciences; scientific journal 


\section{PENDAHULUAN}

Ditengah isu miring efektivitas pemanfaatan bahan perpustakaan, keputusan pengembangan koleksi kembali dipertanyakan. Fakta tidak digunakannya 97\% koleksi e-resources di Perpusnas RI (Nurmalia et al., 2016:68) merupakan momen penting bagi perpustakaan menengok ulang teknik pengembangan koleksinya. Tidak hanya berlaku tunggal, seluruh perpustakaan yang melakukan fungsi untuk memenuhi kebutuhan, baik pendidikan ataupun riset, penting melihat strategi dalam memilih koleksi. Untuk memenuhi kebutuhan penelitian, pengembangan koleksi akan melahirkan banyak pertimbangan. Kendati dewasa ini pertimbangannya cenderung berkutat soal pendanaan. Sangat realistis, mengingat perpustakaan berkewajiban menyesuaikan ketersediaan dana dengan kebutuhan pemustakanya. Apalagi di Indonesia, pemerintahnya rutin menginstruksikan efisiensi anggaran. Dengan keterbatasan anggaran, seleksi koleksi untuk memenuhi kebutuhan penelitian akan semakin kritis dan menantang.

Manfaat dari pengembangan koleksi cenderung terlupakan, bahkan terkadang dilihat sebelah mata. Situasi ini belum sepenuhnya disadari oleh pemangku kepentingan yang terbiasa mengukur efektivitas berdasarkan kapasitas unduhan, jika dikaitkan dengan eresources. Padahal imbas dari pengembangan koleksi, tidak terhitung seberapa banyak para profesional, ahli, atau pakar yang berhasil dicetak. Kondisi ini relevan ketika direlasikan dengan keterpakaian koleksi perpustakaan guna merampungkan disertasi atau tesis mereka. Demikian juga menuntaskan kegiatan riset guna penyebarluasan hasilhasilnya. Bahkan jika tersebarluas ke publikasi bereputasi internasional atau terindeks prestise, reputasi institusi dan negara si pemangku kepentingan turut terangkat. Dalam kondisi yang obyektif, indikator keterpakaian koleksi dalam publikasi semacam itu lebih relevan dibandingkan total unduhan. Sering kali indikator unduhan dijadikan isu-isu inefisiensi anggaran yang mengakibatkan pengembangan koleksi kurang mendapat legitimasi.

Belakangan ini Indonesia terus membangun kepercayaan dalam ajang publikasi internasional. Ini masih menjadi problem serius disaat posisi Indonesia masih berada di urutan ke-55 (SCImago, 2017). Upaya menaikan kepercayaan hingga kini masih dilakukan secara bertahap agar daya saing bangsa mampu mengikuti persaingan global. Melalui program internasionalisasi, publikasi seperti jurnal ilmiah terus ditingkatkan mutunya. Jurnal-jurnal yang kini terindeks seperti di DOAJ atau Index Copernicus, didorong hingga memenuhi standard Scopus. Selain di DIKTI, LIPI termasuk institusi pembina yang mendorong program internasionalisasi. Hingga Desember 2016, program ini diikuti empat institusi dengan total enam jurnal (http://pusbindiklat.lipi.go.id). Diantara tiga bidang, geosains (kebumian) termasuk yang diinisiasi dua institusi, Kementerian ESDM dan LIPI. Untuk itu sumber literatur yang mengilhami penulisan artikel di jurnal program internasionalisasi bidang geosains, dikaji sebagai rekomendasi pengembangan koleksi serial perpustakaan.

Untuk mengkaji sumber-sumber referensi yang terdapat pada artikel jurnal di atas, digunakan analisis sitasi. Tujuan kajian terbagi dalam tiga indikator untuk memberi hasil yang komprehensif sebagai pertimbangan keputusan pengembangan koleksi. Adapun tujuannya yaitu: 
mendeteksi frekuensi keterpakaian jurnal, (2) menginvestigasi usia sitasi maupun penerbit jurnal ilmiah, dan (3) menyelidiki indeks tertimbang (weight index) jurnal yang di sitasi. Dari hasil analisis sitasi ini, perpustakaan mempunyai informasi prioritas kebutuhan koleksi jurnal sebagai dasar pengambilan keputusan. Hasil kajian juga berprospek mendorong pemakaian jurnal secara konsisten dan besar-besaran untuk meningkatkan kualitas artikel. Dengan demikian mampu menambah jurnal-jurnal geosains lain ke dalam program internasionalisasi.

\section{TINJAUAN PUSTAKA}

Pengembangan koleksi dapat diartikan sebagai kegiatan yang bertujuan menjaga agar koleksi perpustakaan tetap mutakhir dan sesuai kebutuhan pemustaka (Perpusnas, 2016:7). Kegiatannya memiliki deretan ruang lingkup diantaranya seleksi koleksi untuk akuisisi. Untuk seleksi terdapat sejumlah teknik antara lain analisis sitasi. Sebagai cabang bibliometrik, analisis sitasi mempelajari kutipan yang terdapat di publikasi untuk mengukur frekuensi dan pola penggunaannya (Johnson, 2014:503; Goodchild et al., 2017:154). Analisis sitasi termasuk teknik yang relatif mudah digunakan pustakawan untuk lebih memahami kebutuhan pemustaka (Hoffmann et al., 2012:326). Menurut Kohn et al. (2014:277) tujuan pengembangan koleksi menggunakan analisis sitasi umumnya untuk mendapatkan kumpulan jurnal. Hal ini tidak mengherankan, jurnal menjadi elemen utama koleksi perpustakaan di seluruh dunia, terutama bentuk elektroniknya (Zhang et al., 2011:67; 2011:828).

Analisis sitasi untuk kepentingan pengembangan koleksi telah banyak diterapkan. Bersumber disertasi dan/atau tesis, sejumlah peneliti menemukan kapasitas sitasi jurnal melampaui sumber referensi lainnya. Antara lain Abeyrathne (2015:33) sebesar 56.71\%, Nagaraja et al. (2015:96) senilai $67.23 \%$, Banateppanvar et al. (2013:12) mencapai 74.77\%, Keogh (2012:211) sebanyak 81.85\%, dan Kaczor (2014:89) hingga 85.1\%. Fakta-fakta ini memberi keyakinan, jurnal mampu berperan dalam mencetak akademisi di atas sarjana. Sumber jurnal juga potensial untuk kepentingan yang sama. Semisal Bullis et al. (2013:119), mengkaji dua jurnal topik terorisme tahun 2007-2009 yang manfaat kajiaannya bisa untuk pengembangan koleksi ilmu sosial. Penting bagi perpustakaan untuk terus mempertahankan dan memprioritaskan koleksi jurnal meskipun dengan anggaran yang terbatas.

Jurnal semakin diperhitungkan ketika kontribusinya terlihat signifikan bagi kemajuan disiplin ilmu. Indikatornya terlihat dari kapasitas sitasinya yang selalu paling unggul untuk pemroduksian artikel jurnal bertaraf Scopus. Diantaranya hingga $48.62 \%$ di jurnal Library Management 2006-2012 (Singh et al., 2014:147), 49.033\% untuk The Electronic Library 2003-2009 (Jena et al., 2012:108), senilai $50.11 \%$ pada Library Review 20072011 (Swain et al., 2013:607), dan 89.61\% (673/751) di International Information and Library Review 2004-2013 (Swain, 2014:121). Bahkan untuk penyusunan artikel di Journal of Pakistan Medical Association, pengutipan jurnal mencapai 90.5\% (Ibrahim et al., 2015:978). Jurnal telah mendapat kredibilitas tinggi dan menginspirasi pengarang untuk menciptakan tulisan bereputasi. Mengorbankan akuisisi jurnal dalam pengembangan koleksi sama halnya mempersulit kerja keras suatu institusi 
atau negara untuk menaikan publikasi internasionalnya.

Penyeleksian jurnal dalam pengembangan koleksi mempertimbangkan banyak faktor. Selain biaya, kemutakhiran dan mutu adalah faktor yang sulit dikesampingkan. Indikator kemutakhiran dapat merujuk sesuai tahun publikasi dengan kriteria paling lama lima tahun terakhir, tergantung topik keilmuannya (LIPI, 2012:27). Terhadap mutu, peringkat jurnal adalah pertimbangan realistis hingga saat ini. Untuk bertaraf internasional dan berbasis indikator sitasi bisa mengadopsi Scimago Journal \& Country Rank (SJR) atau Journal Citation Report (JCR) sebagai instrumen peringkat jurnal alternatif (Todeschini et al., 2016:226). Saat SJR atau JCR dianggap bukan satu-satunya instrumen penilaian yang berdiri sendiri, perpustakaan dapat menawarkan suatu rekomendasi ekstra.

Sebagai tambahan ditawarkan rumus weight index (indeks tertimbang) yang dirancang Waugh et al. (2004:280). Formulanya, Weight $=(\mathrm{T} / \mathrm{D}) \times \mathrm{C}$, didefinsikan kapasitas mahasiswa yang mensitasi jurnal tertentu ( $\mathrm{T})$, dibagi dengan jumlah disertasi dan/atau tesis (D). Hasilnya dikalikan frekuensi sitasi jurnal dimaksud (C). Dalam kajiannya, analisis sitasi mengambil sumber data disertasi, tesis, dan karya riset mahasiswa di Southern Illinois University. Untuk pengembangan koleksi, peringkat jurnal akan tersusun lebih akurat dan tidak didasarkan frekuensi sitasi semata. Jumlah pemustaka yakni mahasiswa dan sitasinya, menentukan besar kecilnya indeks yang didapat. Jika melihat tiga sumber datanya, orang yang sama berpeluang muncul kembali pada sumber lainnya. Misalnya nama tertentu di karya riset, bisa kembali muncul di disertasi dan/atau tesis. Demikian juga orang yang sama muncul di tesis dan disertasi. Peluang ini akan tertutup bila sumber datanya tunggal. Untuk hal semacam ini, terlihat dari praktik weight index bersumber disertasi yang diteliti Griffin (2011:230; 2016:13), Kayongo et al. (2012:57), dan Emerson (2014:49). Apabila merujuk Waugh et al. (2004:279) dimana datanya tidak hanya berpatokan satu sumber semata seperti tesis atau disertasi, muncul sebuah usulan, formula weight index diterapkan terhadap kumpulan artikel jurnal.

\section{METODOLOGI PENELITIAN}

Kajian ini mengambil data dari daftar referensi yang terdapat di artikel jurnal topik geosains program internasionalisasi. Sumbernya berasal dari pangkalan data (Tabel 1) kurun waktu 2014-2016. Untuk kebutuhan analisis, elemen referensi di separasi dan pemanfaatannya terbatas pada tahun terbit, judul publikasi, serta jenis koleksi. Judul publikasi akan di validasi guna memastikan keakurasian dua elemen lainnya, memakai Google Scholar dan/atau Google. Terhadap jurnal yang berganti nama, perhitungan jumlah sitasinya digabungkan dengan judul terbarunya. Lantas untuk menentukan impact factor digunakan SJR (http:/ / www.scimagojr.com), dengan alternatif lainnya yaitu Journal Metrics (https://journalmetrics.scopus.com).

Instrumen alternatif ini dirujuk sebagai sarana pembanding dalam rangka kepentingan validasi.

Untuk keperluan pengukuran indeks tertimbang (WI) jurnal, total penulis yang terdapat pada artikel juga direkam. Berpedoman straight counting (penulis pertama), nama yang disebut berulang saat mensitasi jurnal tertentu tetap dihitung sekali. Kajian ini mencatat pentingnya verifikasi nama penulis untuk menilai kekonsistenan, berbasis 
afiliasinya. Adakalanya penulis yang sama, berciri lebih dari satu suku kata, ditulis sebagiannya dengan singkatan. Demikian juga akibat tanda spasi atau nama penulis dengan ejaan lama dan baru. Sementara itu pengukuran WI menggunakan: rata-ratanya mencapai 23.86 sitasi dengan rentang kemunculan 6 hingga 68 referensi. Sesuai tujuan kajian, referensi-referensi yang berhasil teridentifikasi, dianalisis dan diekspos ke dalam tiga sub pembahasan.

WI $\left(\right.$ Jurnal-J) $=\frac{\Sigma \text { Penulis yang Mensitasi }(\text { Jurnal-J) }}{\Sigma \text { Artikel }(2014-2016)} \times$ Frekuensi Sitasi $($ Jurnal-J)

Selain untuk merekam data, Ms. Excel kembali dimanfaatkan guna mempelajari tabulasi data, termasuk pemeringkatan. Kemudian untuk perhitungan angkaangka statistik, pemrosesan data, dan grafik (Terekhov, 2017:1220). Untuk pemeringkatan, penyusunannya dilakukan secara alfabet mulai dari jumlah tertinggi hingga yang terkecil. Sedangkan untuk memudahkan observasi maka tabulasi disederhanakan, dipindahkan, dan selanjutnya diterjemahkan secara deskriptif.

Tabel 1. Jurnal ilmiah bidang geosains program internasionalisasi LIPI

\begin{tabular}{lcc}
\hline $\begin{array}{l}\text { Nama Jurnal } \\
\text { (Penerbit) }\end{array}$ & Pangkalan Data & $\begin{array}{c}\text { Kapasitas } \\
\text { Sampel }\end{array}$ \\
\hline $\begin{array}{l}\text { Indonesian } \\
\text { Journal on }\end{array}$ & A K \\
$\begin{array}{l}\text { Geoscience } \\
\text { (Badan }\end{array}$ & 45 \\
Geologi, & & \\
Kementerian & & \\
ESDM) & \\
\hline Marine & \\
Research in & \\
Indonesia & \\
(Pusat & 28 \\
Penelitian http://mrijournal.or.id & Artikel \\
Oseanografi, & \\
LIPI) & \\
\hline
\end{tabular}

\section{HASIL PENELITIAN DAN PEMBAHASAN}

Dari hasil pemeriksaan terhadap sampel artikel yang di analisis, 1.742 referensi dipergunakan penulis untuk memproduksi 73 artikel. Adapun jumlah

\section{a. Keterpakaian Terbitan Berkala}

Setelah dilakukan pemetaan sumber referensi, ditemukan sembilan jenis literatur dan jurnal menempati posisi terbaik hingga 58.27\% (Gambar 1). Hasil ini kembali menegaskan, posisi jurnal begitu diperhitungkan untuk kesuksesan penulisan artikel. Deretan fakta yang telah dikemukakan sebelumnya dan kini pada topik geosains, membuat jurnal kian digdaya di kalangan peneliti. Bagi peneliti/penulis, jurnal digunakan dengan berbagai alasan. Dari lima alasan, Nisha et al. (2012:61) mengekspos bahwa kepentingan riset untuk tesis/disertasi/proyek serta publikasi artikel menjadi latar belakang utama mengapa pengguna memanfaatkan jurnal. Kedua alasan ini terbilang relevan karena imbasnya signifikan bagi penciptaan kader-kader pakar, termasuk untuk kemajuan sains. Kendati dihadapkan dengan keterbatasan anggaran, mengorbankan jurnal dalam pengembangan koleksi adalah tindakan berkategori risiko tinggi.

Sementara itu dalam memproduksi 73 artikel geosains, 408 judul jurnal dimanfaatkan penulis dengan frekuensi sitasi bervariasi (Gambar 2). Pemanfaatan secara berulang masih lebih kecil atau $40.2 \%$ dari jumlah judul yang teridentifikasi. Pola pemanfaatan sekali pakai sepertinya menjadi hal biasa. 
Kendati besarannya dapat melebihi dari hasil yang diungkap dalam kajian ini yakni sebesar 59.8\%. Misalnya Kelly (2015:868) yang menemukan 62.1 hingga $80.0 \%$ jurnal hanya di sitasi untuk satu artikel saja. Kemudian Griffin (2011:235) mencapai $61.0 \%$, Barnett-Ellis et al. (2016:9) sebanyak 61.2\% (440/719), dan Delwiche (2016:23) sebesar 64.5\% (526/815). Kesempurnaan kegiatan riset ataupun publikasi ilmiah bidang tertentu adakalanya tidak hanya dipengaruhi satu disiplin ilmu semata. Subjek lain bisa juga berkontribusi kendati tidak menonjol atau sekedar melengkapi topik utamanya. Dampaknya, pola sekali sitasi terhadap satu artikel mempunyai peluang yang besar. Oleh karena itu tidak patut jika menilai dan berpandangan bahwa faktafakta di atas merupakan cerminan kurang berhasilnya pengembangan koleksi jurnal di perpustakaan.

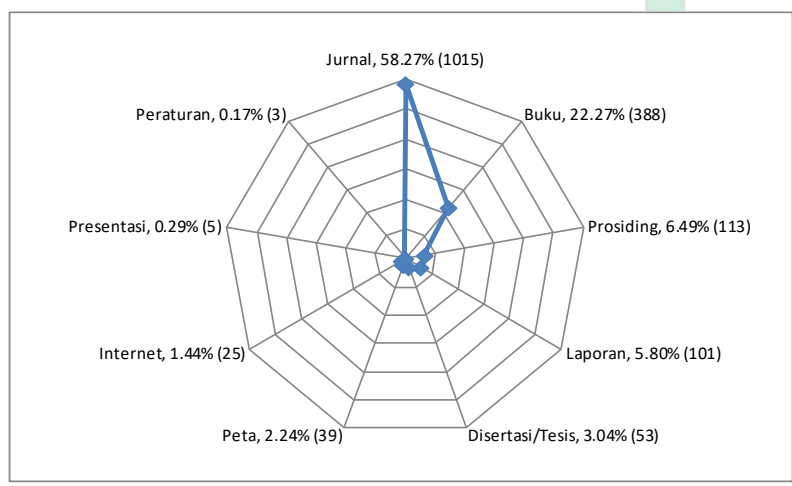

Gambar 1. Keterpakaian sumber referensi

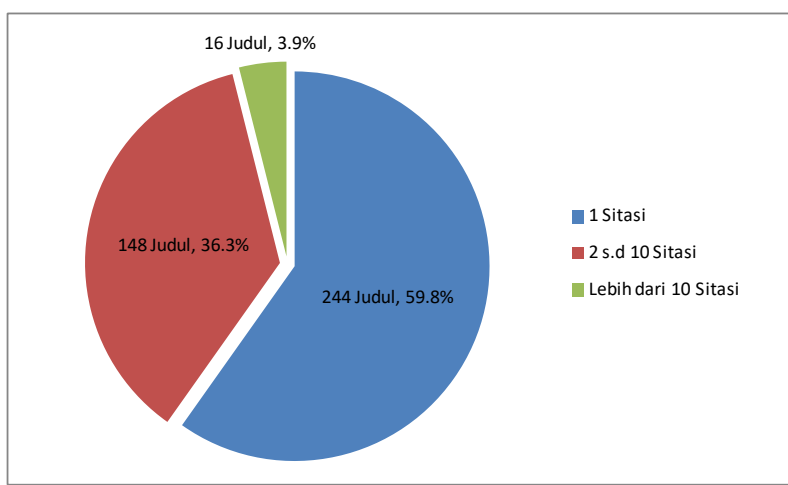

Gambar 2. Distribusi sitasi berdasarkan judul jurnal ilmiah

\section{b. Usia Sitasi dan Penerbit Jurnal}

Sebuah histogram sitasi jurnal ilmiah berdasarkan usia ditampilkan pada Gambar 3. Tingkat kemutakhiran lima tahun terakhir diketahui sebesar $21.5 \%$. Sedangkan kumulatif hingga sepuluh tahun mencapai $41.0 \%$. Sementara itu terdapat kecenderungan, semakin tinggi usia jurnal, diikuti penurunan frekuensi sitasi. Kajian ini juga mendapati rerata usia jurnal yang di sitasi senilai 17.06 dengan rentang 0-126 tahun. Rentang ini lebih pendek dari bidang sejenis yang pernah dilaporkan Kaczor (2014:96), Kimball et al. (2013:362), Wiley (2014:85), dan Stephens et al. (2013:455), masingmasing 295, 323, 170 (1843-2013), serta 130 tahun. Pengutipan jurnal berusia lama mungkin terkait reputasi yang tinggi atau paling tidak menjadi bukti bahwa mutunya terbangun dengan baik. Bagi perpustakaan, distribusi usia sitasi dapat dimanfaatkan untuk manajemen koleksi jurnal dalam hal penyediaan akses, penyimpanan, dan penyiangannya.

Salah satu kriteria umum dalam menseleksi jurnal adalah reputasi dan kualifikasi penerbitnya (Johnson et al., 2014:107). Pada kajian ini, ditemukan 191 penerbit yang sebagiannya ditampilkan dengan keterwakilan $79.21 \%$ dari jumlah sitasi jurnal (Tabel 1). Setengah lebih sitasi jurnal atau $52.91 \%$ diketahui berasal dari penerbit berkelas seperti Elsevier, Wiley, dan Springer. Bukan hanya di geosains, ketiganya juga menguasai serta berdampingan sama persis pada cabang ilmu lainnya (Keogh, 2012:218), bahkan terkadang sekedar bertukar posisi (Dees, 2016:56). Sumber teranyar juga menyebutkan, penerbit dimaksud masuk dalam peringkat tiga besar yang memasok terbitan terindeks Scopus hingga 23\% (Elsevier, 2017:3). Antusiasme pemakai yang tercermin pada Tabel 2 bisa menjadi landasan bagi perpustakaan untuk terus 
mempertahankan penerbit-penerbit berkelas di kegiatan pengembangan koleksi jurnal.

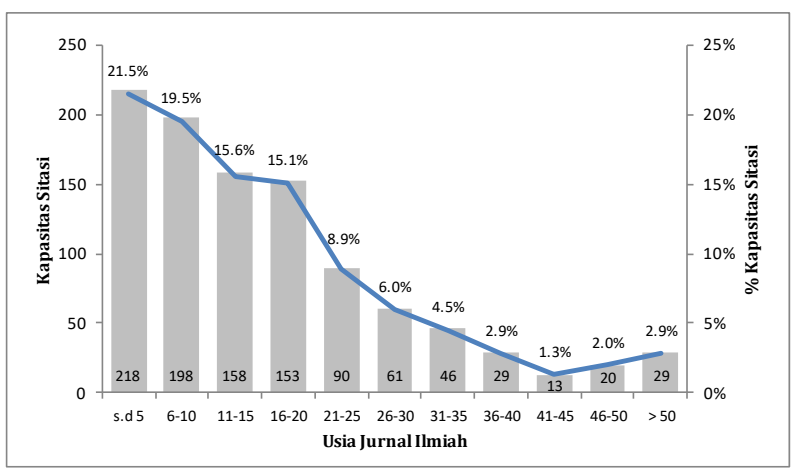

Gambar 3. Histogram usia sitasi jurnal ilmiah

Tabel 2. Sebaran penerbit terbitan berkala bidang geosains

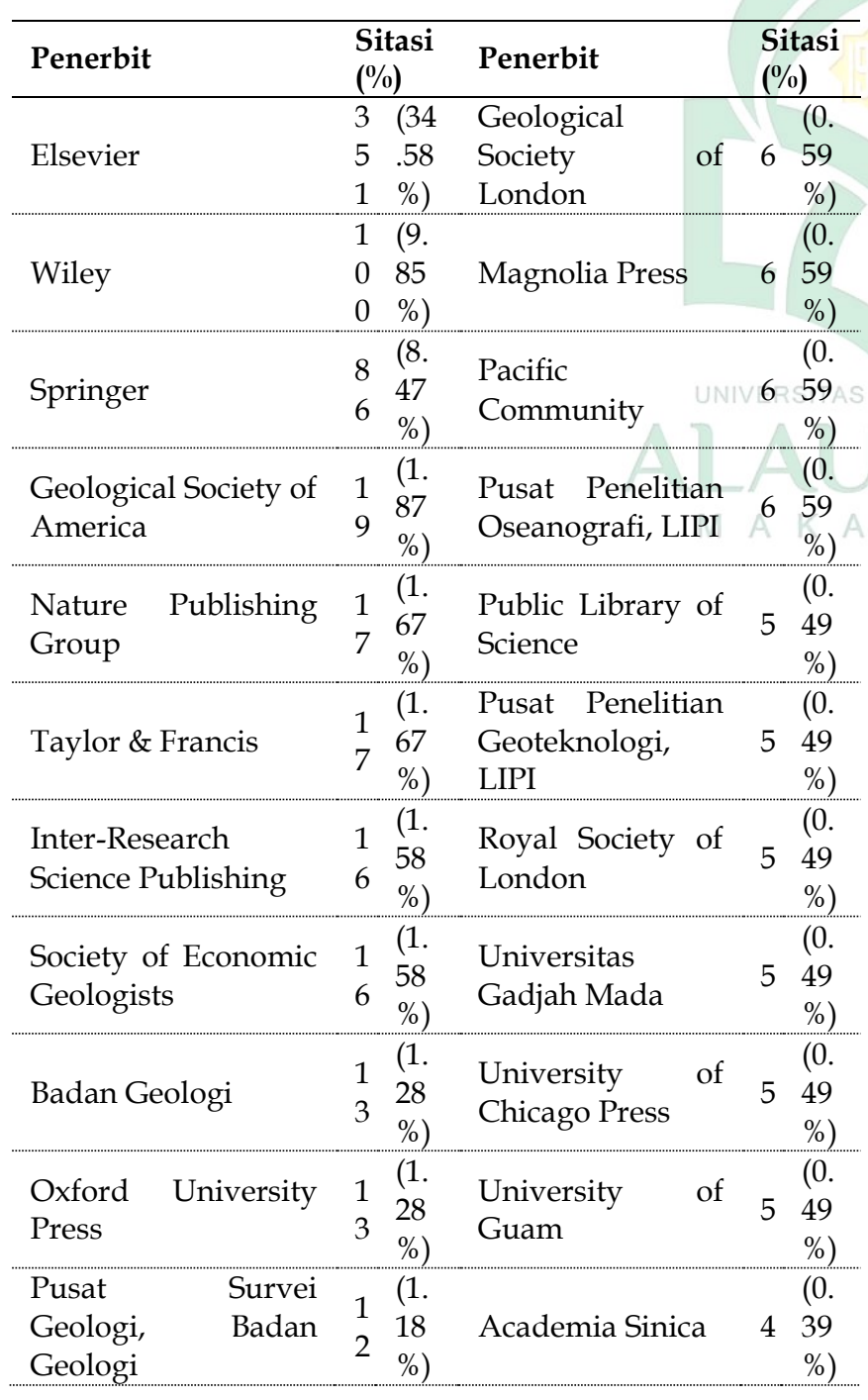

\begin{tabular}{|c|c|c|c|}
\hline Penerbit & $\begin{array}{l}\text { Sitasi } \\
(\%)\end{array}$ & Penerbit & $\begin{array}{l}\text { Sitasi } \\
(\%)\end{array}$ \\
\hline $\begin{array}{l}\text { Puslit. Oseanografi } \\
\text { dan } \\
\text { Limnologi, LIPI }\end{array}$ & $\begin{array}{ll}1 & (1 . \\
1 & 08 \\
& \%)\end{array}$ & $\begin{array}{l}\text { Ikatan } \\
\text { Geologi } \\
\text { Indonesia }\end{array}$ & $\left.\begin{array}{ll} & (0 . \\
4 & 39 \\
\%\end{array}\right)$ \\
\hline $\begin{array}{l}\text { American Assoc. for } \\
\text { the Advancement of } \\
\text { Science }\end{array}$ & $\begin{array}{ll} & (0 . \\
9 \quad 89 \\
\%)\end{array}$ & $\begin{array}{l}\text { Indian Academy } \\
\text { of Sciences }\end{array}$ & $\begin{array}{l}(0 . \\
4 \quad 39 \\
\%)\end{array}$ \\
\hline $\begin{array}{l}\text { American Society } \\
\text { for Microbiology }\end{array}$ & $\left.\begin{array}{ll} & (0 . \\
9 & 89 \\
\%\end{array}\right)$ & $\begin{array}{l}\text { Institut Pertanian } \\
\text { Bogor }\end{array}$ & $\begin{array}{l}(0 . \\
4 \quad 39 \\
\%)\end{array}$ \\
\hline $\begin{array}{l}\text { Cambridge } \\
\text { University Press }\end{array}$ & $\begin{array}{ll} & (0 . \\
8 & 79 \\
& \%)\end{array}$ & $\begin{array}{l}\text { Institut } \\
\text { Teknologi } \\
\text { Bandung }\end{array}$ & $\left.\begin{array}{ll}(0 . \\
4 & 39 \\
\%\end{array}\right)$ \\
\hline $\begin{array}{l}\text { American Assoc. of } \\
\text { Petroleum } \\
\text { Geologists }\end{array}$ & 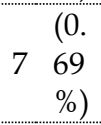 & $\begin{array}{l}\text { National } \\
\text { Academy } \\
\text { Sciences }\end{array}$ & $\begin{array}{l}(0 . \\
4 \quad 39 \\
\%)\end{array}$ \\
\hline $\begin{array}{l}\text { American Chemical } \\
\text { Society }\end{array}$ & $\left.\begin{array}{ll}7 & (0 . \\
7 & 69 \\
\%\end{array}\right)$ & $\begin{array}{l}\text { Persatuan } \\
\text { Geologi Malaysia }\end{array}$ & $\left.\begin{array}{ll} & (0 . \\
4 & 39 \\
\%\end{array}\right)$ \\
\hline $\begin{array}{l}\text { Universitas } \\
\text { Diponegoro }\end{array}$ & $\left.\begin{array}{ll}7 & (0 . \\
7 & 69 \\
\%\end{array}\right)$ & SEPM & $\left.\begin{array}{ll} & (0 . \\
4 & 39 \\
\%\end{array}\right)$ \\
\hline
\end{tabular}

Sumber: data primer yang diolah, 2017

\section{c. Indeks Tertimbang Jurnal}

Implementasi indeks tertimbang terhadap 408 jurnal telah menghasilkan pemeringkatan yang tersaji di Tabel 2. Jika indeks tertimbangnya sama, pemeringkatan diuji kembali melalui instrumen IF-SJR. Dalam kajian ini, jumlah jurnal yang ditampilkan sekurangnya pernah di sitasi empat kali. Dari hasil pemeriksaan setiap jurnalnya, jumlah pemakai berada pada kisaran satu hingga sepuluh orang. Baik pengarang pertama dan pendukung, nama yang unik jumlahnya mencapai 174 orang. Dengan straight counting, total nama unik pengarang menjadi 64 orang dan tidak seimbang dengan kapasitas artikel yang dianalisis.

Sementara itu hasil pada Tabel 3 mengindikasikan bahwa konsumsi referensi tidak selamanya dipengaruhi jurnal-jurnal terindeks Scopus. Untuk keberhasilan diseminasi artikel topik geosains, para pengarang terbilang antusias memilih jurnal yang diprakarsai penerbit Indonesia. Antara lain 
Indonesian Journal on Geoscience serta Oseanologi dan Limnologi di Indonesia. Keduanya juga masuk dalam peringkat sepuluh besar dan mampu bersaing dengan jurnal bereputasi lainnya. Kajian ini sekaligus mengkonfirmasi bahwa judul serial yang di sitasi cenderung memiliki kesamaan dengan fakta-fakta sebelumnya. Diantaranya temuan Anilkumar et al. (2013:118) mengenai sepuluh jurnal favorit untuk riset geosains serta daftar terbitan berkala yang diungkap Putirka (2016:497). Melihat trennya, jurnal yang telah teruji manfaatnya sebaiknya tetap diproritaskan untuk diakuisisi. Untuk itu kesinambungan dan percepatan internasionalisasi jurnal-jurnal geosains di Indonesia termasuk mengandalkan konsistensi perpustakaan dalam memasok koleksi serial tepat guna dan bermutu.

Tabel 3. Peringkat jurnal berdasarkan indeks tertimbang

\begin{tabular}{|c|c|c|c|c|c|c|}
\hline $\begin{array}{c}\mathrm{Pe} \\
\text { ri } \\
\text { ng } \\
\text { ka } \\
\mathrm{t}\end{array}$ & $\begin{array}{c}\text { Judul Terbitan } \\
\text { Berkala }\end{array}$ & WI & JP & FS & $\% \mathrm{FS}$ & IF-SJR \\
\hline 1 & $\begin{array}{l}\text { Marine Pollution } \\
\text { Bulletin }\end{array}$ & 4.068 & 9 & 33 & 3.25 & 1.302 \\
\hline 2 & $\begin{array}{l}\text { Journal of Asian } \\
\text { Earth Sciences }\end{array}$ & 2.342 & 9 & 19 & $1.87 \mathrm{~V}$ & 1.348 \\
\hline 3 & $\begin{array}{l}\text { Journal of } \\
\text { Geophysical } \\
\text { Research }\end{array}$ & 2.082 & 8 & 19 & 1.87 & 1.996 \\
\hline 4 & Tectonophysics & 1.753 & 8 & 16 & 1.58 & 1.706 \\
\hline 5 & $\begin{array}{l}\text { Marine Ecology } \\
\text { Progress Series }\end{array}$ & 1.753 & 8 & 16 & 1.58 & 1.279 \\
\hline 6 & $\begin{array}{l}\text { Indonesian Journal } \\
\text { on Geoscience }\end{array}$ & 1.507 & 10 & 11 & 1.08 & 0.000 \\
\hline 7 & Nature & 1.479 & 9 & 12 & 1.18 & 18.134 \\
\hline 8 & $\begin{array}{l}\text { Oseanologi dan } \\
\text { Limnologi di } \\
\text { Indonesia }\end{array}$ & 1.205 & 8 & 11 & 1.08 & 0.000 \\
\hline 9 & $\begin{array}{l}\text { Palaeogeography, } \\
\text { Palaeoclimatology, } \\
\text { Palaeoecology }\end{array}$ & 1.151 & 7 & 12 & 1.18 & 1.303 \\
\hline 10 & $\begin{array}{l}\text { Estuarine, Coastal } \\
\text { and Shelf Science }\end{array}$ & 1.096 & 5 & 16 & 1.58 & 0.997 \\
\hline 11 & $\begin{array}{c}\text { International } \\
\text { Journal of Coal } \\
\text { Geology }\end{array}$ & 1.041 & 4 & 19 & 1.87 & 1.843 \\
\hline 12 & Economic Geology & 0.877 & 4 & 16 & 1.58 & 1.651 \\
\hline 13 & Geology & 0.863 & 7 & 9 & 0.89 & 3.112 \\
\hline
\end{tabular}

\begin{tabular}{|c|c|c|c|c|c|c|}
\hline 14 & Science & 0.863 & 7 & 9 & 0.89 & 13.535 \\
\hline 15 & $\begin{array}{c}\text { Environmental } \\
\text { Pollution } \\
\end{array}$ & 0.740 & 3 & 18 & 1.77 & 1.786 \\
\hline 16 & $\begin{array}{c}\text { Geochimica et } \\
\text { Cosmochimica Acta }\end{array}$ & 0.685 & 5 & 10 & 0.99 & 2.626 \\
\hline 17 & $\begin{array}{c}\text { Jurnal Sumber } \\
\text { Daya Geologi }\end{array}$ & 0.616 & 5 & 9 & 0.89 & 0.000 \\
\hline 18 & $\begin{array}{c}\text { Contributions to } \\
\text { Mineralogy and } \\
\text { Petrology }\end{array}$ & 0.548 & 5 & 8 & 0.79 & 2.235 \\
\hline 19 & $\begin{array}{c}\text { Journal of } \\
\text { Geochemical } \\
\text { Exploration } \\
\end{array}$ & 0.548 & 4 & 10 & 0.99 & 1.047 \\
\hline 20 & Resource Geology & 0.534 & 3 & 13 & 1.28 & 0.517 \\
\hline 21 & AAPG Bulletin & 0.479 & 5 & 7 & 0.69 & 1.900 \\
\hline 22 & $\begin{array}{c}\text { Journal of } \\
\text { Experimental } \\
\text { Marine Biology and } \\
\text { Ecology }\end{array}$ & 0.479 & 5 & 7 & 0.69 & 0.937 \\
\hline 23 & $\begin{array}{c}\text { Journal of the } \\
\text { Marine Biological } \\
\text { Asso. of the United } \\
\text { Kingdom }\end{array}$ & 0.479 & 5 & 7 & 0.69 & 0.382 \\
\hline 24 & Chemical Geology & 0.452 & 3 & 11 & 1.08 & 1.810 \\
\hline 25 & $\begin{array}{c}\text { Journal of } \\
\text { Volcanology and } \\
\text { Geothermal } \\
\text { Research } \\
\end{array}$ & 0.438 & 4 & 8 & 0.79 & 1.801 \\
\hline 26 & Aquaculture & 0.438 & 2 & 16 & 1.58 & 1.101 \\
\hline 27 & $\begin{array}{c}\text { Bulletin of the } \\
\text { Geological Society } \\
\text { of America }\end{array}$ & 0.411 & 3 & 10 & 0.99 & 2.426 \\
\hline 28 & $\begin{array}{c}\text { Journal of } \\
\text { Structural Geology }\end{array}$ & 0.370 & 3 & 9 & 0.89 & 1.466 \\
\hline 29 & $\begin{array}{l}\text { Limnology and } \\
\text { Oceanography }\end{array}$ & 0.329 & 4 & 6 & 0.59 & 1.712 \\
\hline 30 & Marine Biology & 0.329 & 4 & 6 & 0.59 & 1.198 \\
\hline 31 & Island Arc & 0.329 & 3 & 8 & 0.79 & 0.638 \\
\hline 32 & $\begin{array}{c}\text { Earth and Planetary } \\
\text { Science Letters }\end{array}$ & 0.274 & 4 & 5 & 0.49 & 3.171 \\
\hline 33 & PLoS ONE & 0.274 & 4 & 5 & 0.49 & 1.201 \\
\hline 34 & $\begin{array}{l}\text { Jurnal RISET } \\
\text { Geologi dan } \\
\text { Pertambangan } \\
\end{array}$ & 0.274 & 4 & 5 & 0.49 & 0.000 \\
\hline 35 & Tectonics & 0.247 & 3 & 6 & 0.59 & 2.326 \\
\hline 36 & $\begin{array}{l}\text { Journal of } \\
\text { Petrology } \\
\end{array}$ & 0.247 & 3 & 6 & 0.59 & 2.317 \\
\hline 37 & $\begin{array}{c}\text { Applied and } \\
\text { Environmental } \\
\text { Microbiology } \\
\end{array}$ & 0.247 & 2 & 9 & 0.89 & 1.691 \\
\hline 38 & $\begin{array}{c}\text { Organic } \\
\text { Geochemistry }\end{array}$ & 0.247 & 3 & 6 & 0.59 & 1.620 \\
\hline 39 & $\begin{array}{c}\text { Bulletin of } \\
\text { Volcanology }\end{array}$ & 0.219 & 4 & 4 & 0.39 & 1.591 \\
\hline 40 & $\begin{array}{l}\text { Ore Geology } \\
\text { Reviews }\end{array}$ & 0.219 & 4 & 4 & 0.39 & 1.523 \\
\hline 41 & Current Science & 0.219 & 4 & 4 & 0.39 & 0.285 \\
\hline 42 & $\begin{array}{c}\text { Procedia Earth and } \\
\text { Planetary Science }\end{array}$ & 0.219 & 4 & 4 & 0.39 & 0.178 \\
\hline 43 & $\begin{array}{l}\text { Majalah Geologi } \\
\text { Indonesia }\end{array}$ & 0.219 & 4 & 4 & 0.39 & 0.000 \\
\hline
\end{tabular}




\begin{tabular}{|c|c|c|c|c|c|c|}
\hline 44 & $\begin{array}{l}\text { Science of The Total } \\
\text { Environment }\end{array}$ & 0.205 & 3 & 5 & 0.49 & 1.621 \\
\hline 45 & Lithos & 0.164 & 3 & 4 & 0.39 & 2.517 \\
\hline 46 & Fuel & 0.164 & 2 & 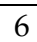 & 0.59 & 1.744 \\
\hline 47 & Chemosphere & 0.164 & 3 & & 0.39 & 1.417 \\
\hline 48 & $\begin{array}{c}\text { Archives of } \\
\text { Environmental } \\
\text { Contamination \& } \\
\text { Toxicology }\end{array}$ & 0.164 & 2 & 6 & 0.59 & 0.826 \\
\hline 49 & Zootaxa & 0.164 & 2 & 6 & 0.59 & 0.358 \\
\hline 50 & $\begin{array}{l}\text { SPC Beche-de-Mer } \\
\text { Information } \\
\text { Bulletin }\end{array}$ & 0.164 & 2 & 6 & 0.59 & 0.000 \\
\hline 51 & Oseana & 0.164 & 3 & 4 & 0.39 & 0.000 \\
\hline 52 & PNAS & 0.164 & 3 & 4 & 0.39 & 6.321 \\
\hline 53 & $\begin{array}{c}\text { Environmental } \\
\text { Science \& } \\
\text { Technology }\end{array}$ & 0.137 & 2 & 5 & 0.49 & 2.538 \\
\hline 54 & Paleoceanography & 0.137 & 2 & 5 & 0.49 & 2.349 \\
\hline 55 & $\begin{array}{c}\text { Journal of } \\
\text { Paleolimnology }\end{array}$ & 0.110 & 2 & 4 & 0.39 & 0.957 \\
\hline 56 & $\begin{array}{c}\text { Journal of } \\
\text { Environmental } \\
\text { Radioactivity }\end{array}$ & 0.110 & 2 & 4 & 0.39 & 0.955 \\
\hline 57 & $\begin{array}{c}\text { Journal of Natural } \\
\text { History }\end{array}$ & 0.110 & 2 & 4 & 0.39 & 0.429 \\
\hline 58 & $\begin{array}{c}\text { Marine } \\
\text { Micropaleontology }\end{array}$ & 0.068 & 1 & 5 & 0.49 & 0.989 \\
\hline 59 & Micronesica & 0.068 & 1 & 5 & 0.49 & 0.000 \\
\hline 60 & Journal of Zoology & 0.055 & 1 & 4 & 0.39 & 1.085 \\
\hline 61 & $\begin{array}{l}\text { Journal of Applied } \\
\text { Phycology }\end{array}$ & 0.055 & 1 & 4 & 0.39 & 0.755 \\
\hline 62 & Zoological Studies & 0.055 & 1 & 4 & 0.39 & 0.532 \\
\hline 63 & $\begin{array}{l}\text { Geological Society } \\
\text { of Malaysia Bulletin }\end{array}$ & 0.055 & 1 & 4 & 0.39 & 0.127 \\
\hline 64 & $\begin{array}{l}\text { Zoologischer } \\
\text { Anzeiger }\end{array}$ & 0.055 & 1 & 4 & 0.39 & 0.722 \\
\hline
\end{tabular}

Sumber: data primer yang diolah, 2017. (WI: indeks tertimbang, JP: jumlah penulis yang mensitasi, FS: frekuensi sitasi)

\section{KESIMPULAN}

Untuk mengembangkan koleksi serial, telah dianalisis 1742 referensi yang tercantum dalam 73 artikel jurnal geosains program internasionalisasi. Fakta menarik yang dijumpai memberi indikasi bahwa jurnal begitu diperhitungkan untuk keberhasilan penulisan artikel. Indikasi ini terlihat dari kapasitas sitasinya hingga $58.27 \%$ yang terpetakan ke dalam 408 jurnal. Keterpakaian jurnal secara berulang sebesar $40.2 \%$, mengindikasikan adanya kontribusi judul-judul lain di luar topik geosains guna kesempurnaan artikel para penulis. Temuan lainnya, usia jurnal yang disitasi memiliki rasio 17.06 dengan rentang 0-126 tahun. Kendati masih lebih pendek dari sejumlah kajian yang pernah dilaporkan, sitasi jurnal berusia tinggi menjadi bukti bahwa kualitasnya terbangun secara baik. Sementara itu distribusi sitasi menurut usia dapat membantu perpustakaan dalam hal penyediaan akses, penyimpanan, dan penyiangan jurnal. Dari jumlah jurnal digunakan, sebanyak 191 penerbit berhasil ditemukan. Elsevier, Wiley, dan Springer lebih diminati penulis, terlihat dari kumulatif sitasinya hingga $52.91 \%$. Tren demikian dapat menjadi landasan untuk mempertahankan penerbit-penerbit bereputasi sebagai penyedia jurnal. Bukti lain yang terungkap, penulisan artikel geosains tak selamanya mengandalkan sumber jurnal terindeks Scopus. Bahkan menurut peringkat indeks tertimbang, jurnal-jurnal Indonesia terlihat mampu bersaing dan teruji manfaatnya. Sebagai upaya kesinambungan serta percepatan internasionalisasi jurnal-jurnal geosains di Indonesia, konsistensi perpustakaan termasuk diandalkan melalui akuisisi koleksi serial tepat guna dan berkualitas.

\section{DAFTAR PUSTAKA}

Abeyrathne, D.K. (2015). Citation analysis of dissertations for collection development. Collection Building, 34(2), 30-40. doi:10.1108/CB-112014-0055

Anilkumar, N., \& Rajaram, S. (2013). Theses submitted by doctoral students of physical research laboratory, India: A citation analysis. Serials Review, 39(2), 114-120.

doi:10.1016/j.serrev.2013.04.002

Banateppanvar, K., Biradar, B., \& Kannappanavar, B. (2013). 
Citation analysis of doctoral theses in botany submitted to Kuvempu University, India: a case study. Collection Building, 32(1), 12-21.

doi:10.1108/01604951311295058

Barnett-Ellis, P., \& Tang, Y. (2016). Usercentered collection development: A citation analysis of graduate biology theses. Collection Management, 41(1), 3-22. doi:10.1080/01462679.2016.114508 8

Bullis, D.R., \& Irving, R.D. (2013). Journals supporting terrorism research: Identification and investigation into their impact on the social sciences. College \& Research Libraries, 74(2), 119-129. doi:10.5860/crl-314

Dees, A.S. (2016). A business citation analysis: A local follow-up study. Journal of Business \& Finance Librarianship, 21(1), 49-59. doi:10.1080/08963568.2015.111245 6

Delwiche, F.A. (2016). Insights gained from analysis of citations in Clinical Laboratory Science. Clinical Laboratory Science, 29(1), 21-27.

Elsevier. (2017). Scopus content coverage guide (Updated August 2017). Retrieved from https:/ / www.elsevier.com/_dat a/assets/pdf_file/0007/69451/05 97-Scopus-Content-CoverageGuide-US-LETTER-v4-HI-singlesno-ticks.pdf

Emerson, S. (2014). Dissertation citation analysis as preparation for supporting a new doctoral program in nursing. Library Collections, Acquisitions, \& Technical Services, 38(3-4), 47-53. doi:10.1080/14649055.2015.105599 8
Goodchild, M., \& Zhao, J. (2017). Sustainability engineering collection assessment: A mixedmethod analysis. Science \& Technology Libraries, 36(2), 153169. doi:10.1080/0194262X.2017.129849 3

Griffin, K.L. (2011). Starting from ground zero: Establishing a collection for a new doctoral program. Behavioral \& Social Sciences Librarian, 30(4), 223-245. doi:10.1080/01639269.2011.622255

Griffin, K.L. (2016). Citation analysis for core journals in educational leadership. Collection Building, 35(1), 12-15. doi:10.1108/CB-072015-0014

Hoffmann, K., \& Doucette, L. (2012). A review of citation analysis methodologies for collection management. College \& Research Libraries, 73(4), 321-335. doi: $10.5860 /$ crl-254

Ibrahim, M., \& Jan, S.U. (2015). Bibliometric analysis of the Journal of Pakistan Medical Association form 2009 to 2013. Journal of Pakistan Medical Association, 65(9), 978-983. Retrieved from http://jpma.org.pk/full_article_te xt.php?article_id=7463

Jena, K.L., Swain, D.K., \& Sahu, S.B. (2012). Scholarly communication of The Electronic Library from 2003-2009: a bibliometric study. The Electronic Library, 30(1), 103119.

doi:10.1108/02640471211204097

Johnson, P. (2014). Fundamentals of collection development and management (3 ed.). American Library Association Editions.

Kaczor, S. (2014). A citation analysis of doctoral dissertations in 
atmospheric science at the University at Albany. Science \& Technology Libraries, 33(1), 89-98. doi:10.1080/0194262X.2013.866067 Kayongo, J., \& Helm, C. (2012). Relevance of library collections for graduate student research: A citation analysis study of doctoral dissertations at Notre Dame. College \& Research Libraries, 73(1), 47-67. doi:10.5860/crl-211

Kelly, M. (2015). Citation patterns of engineering, statistics, and computer science researchers: An internal and external citation analysis across multiple engineering subfields. College \& Research Libraries, 76(7), 859-882. doi:10.5860/crl.76.7.859

Keogh, P. (2012). Resource use by pharmacy graduate students: dissertations and theses as collection development tools. Science \& Technology Libraries, 31(2), 200-229. doi:10.1080/0194262X.2012.676889

Kimball, R., Stephens, J., Hubbard, D., \& Pickett, C. (2013). A citation analysis of atmospheric science publications by faculty at Texas A\&M University. College \& Research Libraries, 74(4), 356-367. doi:10.5860/crl-351

Kohn, K.C., \& Gordon, L. (2014). Citation analysis as a tool for collection development and instruction. Collection Management, 39(4), 275-296. doi:10.1080/01462679.2014.935904

Lembaga Ilmu Pengetahuan Indonesia. (2012). Pedoman Karya Tulis Ilmiah. Peraturan Kepala Lembaga Ilmu Pengetahuan Indonesia Nomor 04/E/2012. Jakarta, 22 November 2012. Retrieved from http:/ / pusbindiklat.lipi.go.id
Nagaraja, A., \& Prashanth, A. (2015). Serials use in post graduates' dissertations of pharmaceutical sciences: collection building by citation analysis. Collection Building, 34(3), 94-101. doi:10.1108/CB-02-2015-0004

Nisha, F., \& P.M., N.A. (2012). Awareness and use of e-journals by IIT Delhi and Delhi University library users. Collection Building, 32(2), 57-64. doi:10.1108/01604951311322039

Nurmalia, I., Kustiyo, A., \& SulistyoBasuki. (2016). Evaluasi Penggunaan Layanan Koleksi EResources Menggunakan Standar Indikator Kinerja (ISO 11620:2014) di Perpustakaan Nasional RI. Jurnal Pustakawan Indonesia, 15(1-2), 58-72. Retrieved from http://journal.ipb.ac.id/index.ph $\mathrm{p} / \mathrm{jpi}$ /issue/view/1872

Perpustakaan Nasional. (2016). Kebijakan Pengembangan Koleksi Perpustakaan Nasional. Peraturan Kepala Perpustakaan Nasional RI Nomor 3 Tahun 2016. Jakarta, 18 Maret 2016. Retrieved from http:/ / www.perpusnas.go.id

Putirka, K. (2016). The most-cited journal in mineralogy and petrology (and what scientists can learn from baseball). American Mineralogist, 101(3), 497-499. doi:10.2138/am2016-Ed10115

SCImago. (2017). SJR - SCImago Journal \& Country Rank. Retrieved from http:/ / www.scimagojr.com

Singh, K., \& Chander, H. (2014). Publication trends in library and information science: A bibliometric analysis of Library Management journal. Library Management, 35(3), 134-149. doi:10.1108/LM-05-2013-0039

Stephens, J., Hubbard, D.E., Pickett, C., \& Kimball, R. (2013). Citation 
behavior of aerospace engineering faculty. The Journal of Academic Librarianship, 39(6), 451-457. doi:10.1016/j.acalib.2013.09.007

Swain, C., Swain, D.K., \& Rautaray, B. (2013). Bibliometric analysis of Library Review from 2007 to 2011. Library Review, 62(8/9), 602-618. doi:10.1108/LR-02-2013-0012

Swain, D. K. (2014). International Information and Library Review: A ten year bibliometric study. International Information \& Library Review, 46(3-4), 113-124. doi:10.1080/10572317.2014.951589

Terekhov, A.I. (2017). Bibliometric spectroscopy of Russia's nanotechnology: 2000-2014. Scientometrics, 110(3), 1217-1242. doi:10.1007/s11192-016-2234-5

Todeschini, R., \& Baccini, A. (2016). Handbook of bibliometric indicators: Quantitative tools for studying and evaluating research. Wiley.

Waugh, C.K., \& Ruppel, M. (2004). Citation analysis of dissertation, thesis, and research paper references in workforce education and development. The Journal of Academic Librarianship, 30(4), 276-284.

doi:10.1016/j.acalib.2004.04.003

Wiley, C.A. (2014). Using citation analysis to explore the collection needs of atmospheric scientists/researchers affiliated with the Atlantic Oceanographic Meteorological Laboratory. Library Collections, Acquisitions, \& Technical Services, 38(3-4), 82-91. doi:10.1080/14649055.2015.108050 9

Zhang, L., Ye, P., \& Liu, Q. (2011). A survey of the use of electronic resources at seven universities in Wuhan, China. Program, 45(1), 67-
77. doi:10.1108/00330331111107402

Zhang, L., Ye, P., Liu, Q., \& Rao, L. (2011). Survey on the utilization of NSTL electronic resources in colleges and universities in Wuhan, China. The Electronic Library, 29(6), 828840. doi:10.1108/02640471111188042 